\title{
CHARAKTERYSTYKA PRZEPISÓW DOTYCZĄCYCH DAROWIZNY OBOWIĄZUJĄCYCH NA ZIEMIACH WSCHODNICH BYŁEGO ZABORU ROSYJSKIEGO POD RZĄDAMI ZWODU PRAW CESARSTWA ROSYJSKIEGO
}

\begin{abstract}
Abstrakt: W okresie zaborów, a także w okresie międzywojennym, na ziemiach wschodnich zaboru rosyjskiego, czyli na tak zwanych Kresach Wschodnich, obowiązywały przepisy o darowiźnie zawarte w tomie X, części 1 rosyjskiego Zwodu praw Cesarstwa Rosyjskiego (Swod zakonow Rossijskoj impierii) z 1832 roku.

W artykule przeprowadzono analizę poszczególnych przepisów dotyczących darowizny zawartych w Zwodzie praw Cesarstwa Rosyjskiego z uwzględnieniem stanowiska doktryny polskiej i rosyjskiej oraz orzecznictwa sądów polskich.

W porównaniu z pozostałymi regulacjami dzielnicowymi — kodeksem cywilnym niemieckim (BGB), kodeksem cywilnym austriackim (ABGB) oraz kodeksem Napoleona — zawarte w Zwodzie praw przepisy dotyczące darowizny charakteryzowały się specyficzną regulacją dotyczącą przede wszystkim szczególnych jej rodzajów (nadanie i ofiara, wydzielenie i posag), a także umiejscowieniem jej w systematyce prawa cywilnego, czyli w części ogólnej, a nie — jak to miało miejsce w pozostałych ustawodawstwach dzielnicowych — w części poświęconej zobowiązaniom.
\end{abstract}

Słowa kluczowe: darowizna, Zwód praw Cesarstwa Rosyjskiego, prawo cywilne w okresie zaborów, prawo cywilne w II RP, kodeks zobowiązań

\section{WSTĘP}

Na ziemiach wschodnich zaboru rosyjskiego, czyli na tak zwanych Kresach Wschodnich ${ }^{1}$, zarówno w okresie zaborów, jak i w dwudziestoleciu międzywojen-

1 Wschodnie ziemie Rzeczypospolitej, przyłączone do Cesarstwa Rosyjskiego podczas kolejnych rozbiorów państwa polskiego, zwane w terminologii urzędowej ,guberniami zachodnimi”, czyli ziemie litewsko-białoruskie i Ukraina. Szerzej zob. K. Sójka-Zielińska, Historia Państwa i Prawa Polski, t. 3. Od rozbiorów do uwłaszczenia, red. J. Bardach, M. Senkowska-Gluck, Warszawa 1981, s. 849-851. 
nym ${ }^{2}$ obowiązywały przepisy o darowiźnie zawarte w tomie X, części 1 Zwodu praw Cesarstwa Rosyjskiego (Swod zakonow Rossijskoj impierii) z 1832 roku $^{3}$ (dalej: t. X, cz. 1) ${ }^{4}$.

Przepisy pomieszczone w art. 967-993 zezwalały na darowiznę tylko majątku nieruchomego i nabytego, a w przypadku majątku rodowego - tylko na rzecz najbliższych spadkobierców. W przeciwieństwie do innych kodeksów pozaborowych w Zwodzie praw nie znalazły się żadne szczególne uregulowania dotyczące darowizny między małżonkami (art. 978 t. X, cz.1). Poza tym w art. 994-1000 znalazły się przepisy o wydzieleniu majątku przez rodziców i wstępnych na rzecz dzieci i potomków, a w art. 1001-1008 przepisy o posagu 5 . Ponadto w art. 934-966 zawarto przepisy o szczególnej odmianie darowizny, czyli o nadaniu (pożałowanije), nazywanym darowizną nieruchomości dokonaną przez naczelnika państwa z majątku państwa na rzecz osoby prywatnej ${ }^{6}$.

Przepisy o darowiźnie w t. X, cz. 1 były lakoniczne i niezupełnie jasne, a mimo to w okresie ich obowiązywania na ziemiach polskich, doktryna nie poświęcała im zbyt wiele miejsca? ${ }^{7}$.

2 W okresie II RP ustawodawstwo rosyjskie obowiązywało na mocy ustawy z dnia 4 lutego 1921 roku (Dz.U. z 1921 r. Nr 16, poz. 93) i ustawy z dnia 6 kwietnia 1922 roku (Dz.U. z 1922 r. Nr 26, poz. 213) oraz rozporządzenia Prezydenta Rzeczypospolitej Polskiej z dnia 26 marca 1927 roku (Dz.U. z 1927 r. Nr 31, poz. 258) w województwach: wołyńskim, poleskim, nowogródzkim, wileńskim oraz w powiatach białostockim, bielskim, sokolskim, grodzieńskim i wołkowyskim województwa białostockiego.

${ }^{3} \mathrm{Na}$ ziemiach wschodnich Zwód praw Cesarstwa Rosyjskiego obowiązywał od roku 1840. Ostatecznie został uchylony w wyniku unifikacji prawa cywilnego po II wojnie światowej, zob. K. Sójka-Zielińska, Historia Prawa, Warszawa 2011, s. 224 i tejże, Historia Państwa i Prawa Polski..., s. 838. Na ziemiach centralnych, czyli w Królestwie Polskim, obowiązywały przepisy o darowiźnie zawarte we francuskim Kodeksie Napoleona z 1804 roku - Code civil des Français $(\mathrm{KN})$, na ziemiach południowych w austriackim kodeksie cywilnym z 1811 roku - Allgemeines bürgerliches Gesetzbuch (ABGB), na ziemiach zachodnich w niemieckim kodeksie cywilnym z 1896 roku - Bürgerliches Gesetzbuch (BGB).

4 Przepisy t. 10, cz. 1 omawiam na podstawie wydania Prawo cywilne Ziem Wschodnich. Tom X, cz. I Zwodu praw Rosyjskich, przekładu nowego dokonali i opracowali Z. Rymowicz, W. Święcicki, t. 1, Warszawa 1932 i t. 2, Warszawa 1933.

5 L. Domański, Instytucje kodeksu zobowiązań. Część szczególna, Warszawa 1938, s. 137-138.

6 Bossowski F., Zoll F., Prawo cywilne dzielnic polskich w zarysie, cz. 4. Prawo cywilne Ziem Wschodnich, na podstawie dzieła Szerszeniewicza oprac. F. Bossowski, Warszawa-Kraków 1922, s. 200-201.

7 W polskiej literaturze oprócz tłumaczenia Z. Rymowicza i W. Święcickiego, którzy poza brzmieniem artykułów zamieścili między innymi orzeczenia Senatu kasacyjnego i orzeczenia sądów polskich, pobieżnie o darowiźnie pisał prof. F. Bossowski z Uniwersytetu Wileńskiego w Prawie cywilnym ziem..., s. 200-202, który swoją monografię opracował na podstawie dzieła G.G. Szerszeniewicza, Uczebnik Russkogo Grażdanskogo Prawa, Moskwa 1912. Ponadto należy wspomnieć o artykule L. Sumoroka, Darowizna wedtug cz. I, t. X. Zwodu praw, „, Wileński Przegląd Prawniczy" 1933, nr 7, s. 181-186, gdzie autor przedstawia głównie stanowisko rosyjskich cywilistów dotyczące zwrotu darowizny. Odwołuje się przede wszystkim do K. Annienkowa, D.I. Mejera, G.F. Szerszeniewicza, K.P. Pobiedonoscewa. 
Przepisy wprowadzające kodeks zobowiązań z 1933 roku $^{8}$ na zasadzie art. XXXV § 1 lit. b9 , uchyliły art. 973-977 z wymienionych powyżej przepisów t. X, cz. 1, pozostawiając w mocy pozostałe ${ }^{10}$.

\section{POJECIE I CHARAKTER PRAWNY DAROWIZNY}

Przepisy t. X, cz. 1 dotyczące darowizny w wielu aspektach różniły się zasadniczo od innych ustawodawstw europejskich. W czasach przed rewolucją z 1917 roku rosyjskie ustawodawstwo cywilne i doktryna prawa cywilnego nie dawały jednoznacznych odpowiedzi na pytania dotyczące pojęcia darowizny, jej charakteru prawnego i miejsca tej instytucji $\mathrm{w}$ systemie prawa cywilnego. Co istotne, w ówczesnym prawie cywilnym przepisy dotyczące darowizn nie były umieszczane wśród przepisów dotyczących zobowiązań umownych, lecz w części dotyczącej trybu nabywania i utwierdzania praw majątkowych ${ }^{11}$.

Było to związane z przekonaniem, że w większości przypadków darowizna ma na celu przeniesienie własności z jednej osoby na drugą i przejście to odbywa się jednocześnie z momentem porozumienia. W związku z tym Konstantin Pietrowicz Pobiedonoscew uważał, że darowizna była środkiem do nabycia praw własności ${ }^{12}$.

Z kolei Gabriel Szerszeniewicz sądził, że sam fakt, że darowizna najczęściej miała na celu przeniesienie własności nie dawał powodu do ignorowania darowizn, które były pozbawione tego celu. Poza tym nawet w przypadku, gdy darowizna miała na celu przeniesienie własności, to moment owego przeniesienia nie zawsze zbiegał się z momentem porozumienia dawcy z wykonawcą, a dopiero to ustanawiało obowiązkową relację między nimi. Według Szerszeniewicza każda darowizna następowała $\mathrm{w}$ drodze porozumienia, które miało bezpośrednio na celu zwiększenie majątku osoby przyjmującej kosztem majątku dawcy. Darowizna miała więc sens tylko wtedy, gdy następowało jej przyjęcie przez obdarowanego. W związku z tym darowiznę charakteryzował stosunek umowny i ze względów

${ }^{8}$ Kodeks zobowiązań (dalej: k.z.) wprowadzony został w życie na mocy rozporządzenia Prezydenta Rzeczypospolitej z dnia 27 października 1933 roku (Dz.U.RP. z 1933 r. Nr 82, poz. 598 i sprost. Dz.U.RP. z 1934 r. Nr 54, poz. 492, ze zm.; oraz Dz.U.RP. z 1933 r. Nr 82, poz. 599 i sprost. Dz.U.RP. z 1934 r. Nr 54, poz. 492, ze zm.), z mocą obowiązującą od 1 lipca 1934 roku.

9 Art. XXXV § 1: „W tomie X, cz. 1 Zwodu praw uchyla się w szczególności: b) z księgi trzeciej art. 973-977, uw. 2 do 1259, 1379, 1380, 1384, 1385, 1389, 1425-1428, 1464-1467, 1511, 1513-1521".

10 L. Domański, op. cit., s. 136-138; w okresie zaborowym część artykułów, to jest art. 968, 971, 972, t. 10, cz. 1, została uchylona. Por. Z. Rymowicz, W. Święcicki, Prawo cywilne Ziem..., s. 575.

11 Przepisy o darowiźnie zalazły się w rozdziale II ( $O$ darowiźnie), księdze III ( $O$ trybie nabywania i utwierdzenia praw majątkowych w szczególności), dziale I (O nabywaniu praw majątkowych pod tytułem darmym czyli bezplatnym).

12 K.P.Pobiedonoscew, Kurs grażdanskogo prawa, t. 3, Sankt Petersburg 1896, s. 365; G.F. Szerszeniewicz, Uczebnik russkogo grażdanskogo prawa, Moskwa 1995, s. 337; M.I. Braginskij, W.W. Witrianskij, Dogowornoje Prawo, Moskwa 2011, s. 284. 
metodologicznych miejsce tej instytucji w systemie prawa cywilnego powinno znajdować się nie w części ogólnej dotyczącej nabywania praw, a w części szczególnej — wśród zobowiązań umownych ${ }^{13}$.

W ten sposób Szerszeniewicz nie zgadzał się z poglądem założyciela rosyjskiego prawa cywilnego, D.I. Meiera, który darowiznę umieszczał w ogólnej części prawa cywilnego. Meier podkreślał, że bezpłatne prawa mogą być nabywane na różne sposoby, na przykład poprzez przeniesienie na podstawie umowy, a zatem metody swobodnego zakupu praw nie są zgrupowane w jednej instytucji, ale w różnych, które określają bezpłatny zakup jednego lub drugiego prawa. W ten sposób można przedstawić ogólną teorię darowizny jako instytucję obejmującą w zarysie wszystkie instytucje o nabywaniu praw nieodpłatnym i bez odszkodowania. W związku $\mathrm{z}$ tym $\mathrm{w}$ nauce o nabywaniu praw znajduje miejsce nauka o darowaniu ${ }^{14}$.

Pomimo sporu rosyjskich cywilistów co do charakteru prawnego darowizny i miejsca tej instytucji w systemie prawa cywilnego, opinie pozostawały zbieżne co do czterech głównych cech umowy darowizny: nieodpłatność, dążenie do zwiększenie majątku obdarowanego, zmniejszenie majątku darczyńcy oraz zamiar darczyńcy przekazania obdarowanemu ${ }^{15}$.

\subsection{NIEODPŁATNOŚĆ}

Wśród znaków darowizny wyróżniano jej nieodpłatność. Z prawnego punktu widzenia bezinteresowność darowizny i jej nieuzasadniona natura oznaczały jedynie, że przekazana wartość nie odpowiada ekwiwalentowi. Jednocześnie uważano, że motywacje darczyńcy, nawet jeśli nie były w żaden sposób bezinteresowne, a rzadko zdarza się, żeby takie były, nie dyskredytują danego aktu jako darowizny ${ }^{16}$. Pobudką daleką od altruizmu mogła być na przykład nagroda za uratowanie życia czy chęć uzyskania przychylności ${ }^{17}$.

\subsection{ZWIĘKSZENIE MAJĄTKU OBDAROWANEGO}

Darowizna zmierzała do zwiększenia majątku osoby obdarowanej z majątku darczyńcy. Mogło to nastąpić przez oddanie obdarowanemu rzeczy na własność, przez ustanowienie lub przeniesienie na niego innych praw, przez ustanowienie na jego rzecz wierzytelności, przez zwolnienie go od zobowiązania lub ograniczenia wpływającego na jego prawa ${ }^{18}$.

13 G.F. Szerszeniewicz, op. cit., s. 337-338; M.I. Braginskij, W.W. Witrianskij, op. cit., s. $282-283$.

14 D.I. Meier, Russkoje grażdanskoje prawo, Sankt Petersburg 1864, s. 233; M.I. Braginskij, W.W. Witrianskij, op. cit., s. 282-283.

15 M.I. Braginskij, W.W. Witrianskij, op. cit., s. 286.

16 D.I. Meier, op. cit., s. 235; G.F. Szerszeniewicz, op. cit., s. 338; M.I. Braginskij, W.W. Witrianskij, op. cit., s. 286-287.

17 F. Bossowski, op. cit., s. 200.

18 Ibidem, s. 200. 
Według Szerszeniewicza zwiększenie majątku obdarowanego powinno być bezpośrednim celem darowizny, a sytuacja, w której wzbogacenie jest elementem losowym i nie stanowi bezpośredniego celu umowy, nie pasuje do koncepcji darowizny ${ }^{19}$.

\subsection{ZMNIEJSZENIE MAJĄTKU DARCZYŃCY}

W przypadku darowizny zwiększenie majątku obdarowanego pociągało za sobą zmniejszenie majątku darczyńcy. Według doktryny rosyjskiej zasada ta pozwalała odróżnić darowiznę od testamentu.

Meier zwrócił uwagę, że darowizna jest wyobcowaniem praw, a w konsekwencji darczyńca po dokonaniu darowizny zostaje pozbawiony jakichkolwiek praw. Jeśli dar miałby przejść na obdarowanego po śmierci darczyńcy, wówczas darowizna miała już formę dyspozycji testamentowej ${ }^{20}$.

Podobne stanowisko zajmował Szerszeniewicz, który podkreślał, że darowizna różni się od testamentu tym, że zgodnie testator pozostawia całą swoją własność lub jego część innej osobie, ale jego własność nie maleje dopóki on żyje; własność ta należeć będzie do spadkobiercy dopiero po śmierci spadkodawcy. Według Szerszeniewicza zasada ta umożliwiała również odróżnienie umowy darowizny od niektórych innych umów ${ }^{21}$.

\subsection{ZAMIAR DARCZYŃCY}

Według prawników rosyjskich jednym z głównych znaków darowizny był zamiar obdarowania przez darczyńcę innej osoby. Według Meiera transakcja wiąże się z wolą osoby do jej ukończenia, a umowa darowizny oznacza, że dawca zamierza obdarzyć inną osobę (animus donandi). W sytuacji, gdy nie było takiej intencji, nie można było mówić o darowiźnie, nawet jeśli wszystkie pozostałe cechy darowizny zostały zachowane ${ }^{22}$.

Poza ogólnym pojęciem darowizny określonym w art. 967-993 t. X, cz. 1 rozróżniano poszczególne jej odmiany. Było to nadanie (pożałowanije), nazywane darowizną nieruchomości dokonaną przez cesarza z majątku państwa na rzecz osoby prywatnej (art. 934-966 t. X, cz. 1), oraz ofiara (pożertwowanije), nazywana darowizną osoby prywatnej na rzecz państwa lub na rzecz innej osoby prawniczej, której cele były ogólnospołeczne (art. 979-986 t. X, cz. 1)²3.

${ }_{19}$ G.F. Szerszeniewicz, op. cit., s. 338; M.I. Braginskij, W.W. Witrianskij, op. cit., s. 287.

20 D.I. Meier, op. cit., s. 234; M.I. Braginskij, W.W. Witrianskij, op. cit., s. 287.

21 G.F. Szerszeniewicz, op. cit., s. 338; M.I. Braginskij, W.W. Witrianskij, op. cit., s. 287-288.

22 D.I. Miejier, op. cit., s. 235-236; G.F. Szerszeniewicz, op. cit., s. 338-339; M.I. Braginskij, W.W. Witrianskij, op. cit., s. 288.

23 Szerzej o tym w dalszej części pracy, w podrozdziale dotyczącym rodzajów darowizny. 


\section{PODSTAWOWE ELEMENTY UMOWY DAROWIZNY}

\subsection{PRZEDMIOT}

Zgodnie z art. 967 t. X, cz. 1 właściciel mógł swobodnie, według swojego uznania, darować swój majątek ruchomy lub nieruchomy. Natomiast nie wolno było darować majątku rodowego krewnym albo obcym z pominięciem sukcesorów najbliższych ${ }^{24}$. Za znaczące dobra uznawano te, które nie mogły być przedmiotem darowizny, a omijanie prawa, które było często praktykowane w odniesieniu do nieruchomości rodzinnych, było zabronione ${ }^{25}$.

Według Meiera przedmiot darowizny oznaczał wszelkie nieuzasadnione, celowe zrzeczenie się jakiegokolwiek prawa własności. Przedmiotem podarunku mogło być dowolne prawo majątkowe, a więc nie tylko prawo własności, które najczęściej stanowiło przedmiot darowizny ${ }^{26}$.

Szerszeniewicz określał przedmiot umowy darowizny poprzez działania darczyńcy, które prowadziły do zwiększenia majątku obdarowanego. Według niego zwiększenie majątku obdarowanego następowało w wyniku: przekazania rzeczy do jego własności; przyznania mu innych praw majątkowych, z którymi korzystanie jest powiązane; ustanowienia zobowiązania, w którym obdarowanemu przysługuje prawo do roszczenia; zwolnienie obdarowanego ze zobowiązania lub zniesienie ograniczenia jego prawa własności ${ }^{27}$.

\subsection{OSOBY BIORĄCE UDZIAŁ W DAROWIŹNIE}

W stosunku do osób uczestniczących w darowiźnie, to jest darczyńcy i obdarowanego, prawo nie nakładało żadnych specjalnych wymagań poza tymi, które zostały ogólnie przyjęte dla pozostałych stosunków cywilno-prawnych. Jedyną kwestią poruszaną przez doktrynę była możliwość uczestnictwa w stosunkach prawnych związanych z darowizną osób będących pod opieką (zarówno w charakterze darczyńców, jak i obdarowanych).

${ }^{24} \mathrm{~W}$ praktyce kwestia związana $\mathrm{z}$ darowizną majątku rodowego przysparzała wiele problemów. Warto przytoczyć zatem kilka orzeczeń, które wyjaśniały te wątpliwości: „Sukcesorami najbliższymi w rozumieniu art. 967 są wszyscy krewni jednakowego stopnia, posiadający prawo spadkobrania, i przeto jeżeli jest kilku spadkobierców tego samego stopnia, każdemu z nich może być podarowana tylko część majątku rodowego, przypadająca na jego schedę” (S.C. 178/79); „Prawo kwestionowania aktu darowizny majątku rodowego służy jedynie spadkobiercom ustawowym darczyńcy, prawo to bowiem jest prawem osobistem członków rodu, z którego pochodzi nieruchomość, i nie może przechodzić wraz z nabyciem tej nieruchomości na osoby postronne, do tego rodu nie należące" (S.N. 189/28), cyt. za: Prawo cywilne Ziem..., s. 573.

25 G.F. Szerszeniewicz, op. cit., s. 339.

26 D.I. Miejier, op. cit., s. 240; M.I. Braginskij, W.W. Witrianskij, op. cit., s. 289.

27 G.F. Szerszeniewicz, op. cit., s. 338; F. Bossowski, op. cit., s. 200; M.I. Braginskij, W.W. Witrianskij, op. cit., s. 290; 
Meier uważał, że darowizna od opiekuna nie powinna być uznawana za ważną, ponieważ ochrona interesów małoletniego była obowiązkiem opiekuna, a darowizna była uznawana za szkodliwą dla darczyńcy, dlatego nie należało dopuszczać do takiej sytuacji. Jednak zgodnie z ustawodawstwem rosyjskim działania opiekuna szkodzące podopiecznemu, nie były uważane za nieważne, a odpowiedzialność ponosił tylko opiekun. Odpowiedzialność opiekuna była jednak warunkowa: jeśli udowodnił, że darowizna jest korzystna dla małoletniego, wtedy nie ponosił żadnej odpowiedzialności.

W podobnym tonie Meier odniósł się do możliwości przekazania darowizny osobie podlegającej opiece. W tym przypadku mogłoby się wydawać, że darowizna taka będzie ważna, ponieważ zawsze przynosi korzyści obdarowanemu. Jednak w rzeczywistości darowizna może okazać się niekorzystna, na przykład gdy podarunek będzie nieopłacalny lub wyrządzi obdarowanemu krzywdę. W związku z tym należało uznać przyjęcie darowizny ze strony opiekuna za ważne, ale jeśli podarunek okazał się niekorzystny dla obdarowanego, wówczas opiekun ponosił za to odpowiedzialnośćc ${ }^{28}$.

\section{OGRANICZENIA DAROWIZNY}

W prawie rosyjskim darowizna podlegała szczególnym ograniczeniom. Stanowiły o tym przepisy art. 985 t. X, cz. 1, zgodnie z którymi przyjęcie darowizny majątku nieruchomego przez cerkwie i klasztory wymagało zezwolenia władzy najwyższej. Wiązało się to z prawem nadzoru nad zarządem majątku cerkiewnego i klasztornego przez władze państwowe ${ }^{29}$.

\section{FORMA DAROWIZNY}

Przepisy dotyczące formy darowizny zawarte zostały w art. 987-993 t. X. cz. $1^{30}$. Znalazły się one w odrębnym oddziale zatytułowanym „O sporządzaniu aktów darowizny i o intromisji na ich podstawie".

Wymagania dotyczące formy umowy darowizny różniły się w zależności od rodzaju umowy darowizny i jej przedmiotu. Wprawdzie t. X, cz. 1 nie wymaga od ważności darowizny żadnej szczególnej formy, jednak skuteczność pewnych aktów realizujących darowiznę już tak, na przykład przeniesienie nieruchomości

${ }^{28}$ D.I. Miejier, op. cit., s. 238-239; M.I. Braginskij, W.W. Witrianskij, op. cit., s. 293.

29 G.F. Szerszeniewicz, op. cit., s. 339; F. Bossowski, op. cit., s. 201; M.I. Braginskij, W.W. Witrianskij, op. cit., s. 294.

$30 \mathrm{Na}$ podstawie przepisów wprowadzających k.z. (art. XXXV) przepisy te pozostawiono w mocy pomimo wejścia w życie k.z. 
wymagało formy aktu pisemnego, gdzie zgodnie z obowiązującymi na Ziemiach Wschodnich przepisami przy nieruchomościach hipotecznych konieczna była forma aktu notarialnego ${ }^{31}$.

Według Szerszeniewicza forma darowizny jest zróżnicowana ze względu na to, że darczyńca albo przenosi prawo własności, albo jest zobowiązany do przeniesienia, albo zrzeka się swojego prawa do roszczenia. Forma pisemna była wymagana, jeśli w wyniku darowizny powstało zobowiązanie, na mocy którego dawca był zobowiązany do przekazania rzeczy w przyszłości, ale jeśli na mocy darowizny przeniesienie własności musiało nastąpić wraz z umową, wówczas forma darowizny różniła się w zależności od tego, czy dotyczyła rzeczy ruchomych czy nieruchomych ${ }^{32}$.

W przypadku przekazywania rzeczy ruchomych forma pisemna nie była wymagana. Stanowił o tym art. 993 t. X, cz. 1, zgodnie z którym wydanie darowizny majątku ruchomego następowało przez doręczenie darowanej rzeczy temu, komu była przeznaczona i przez jej przejście do jego rozporządzenia. Zatem darowizna rzeczy ruchomej nie wymagała formy pisemnej i dokonywała się albo przez wydanie tej rzeczy obdarowanemu, albo - gdy jej faktyczne wydanie nie nastąpiło - przez sporządzenie zobowiązania pisemnego ${ }^{33}$. Darowizna dokonująca się poprzez przekazanie rzeczy ruchomej danej osobie powodowała przejście prawa własności na tę osobę od momentu przekazania tej rzeczy ${ }^{34}$.

Natomiast darowizna nieruchomości połączona była $\mathrm{z}$ ogólnymi formalnościami ustalonymi dla przekazania nieruchomości. Stanowił o tym art. 987 t. X, cz.1, według którego akty darowizny dotyczące majątków nieruchomych sporządzało się zgodnie z postanowieniami ustawy notarialnej przy zachowaniu postanowień szczególnych zawartych w art. 988-992 t. X, cz. 1.

W tym przypadku darowizna jako obowiązek była skuteczna od momentu zawarcia umowy $\mathrm{w}$ formie ustanowionej przez prawo dla przeniesienia własności. W związku z tym, że formularz ten składał się z kilku odrębnych czynności (wykonanie aktu przez notariusza, zatwierdzenie przez starszego notariusza), uznawano, że do końca całej ceremonii umacniania spadkobierców darczyńcy można było

31 E. Till, R. Longchamps de Berier, Polskie prawo zobowiąań (część szczegółowa). Projekt wstępny z motywami, Lwów 1928, s 112-113; F. Bossowski, op. cit., s. 201; R. Longchamps de Berier, Uzasadnienie projektu kodeksu zobowiazań, art. 294-369, „Komisja Kodyfikacyjna. Podkomisja Prawa o Zobowiązaniach" 1937, z. 7, s. 94-95.

32 G.F. Szerszeniewicz, op. cit., s. 339-340; M.I. Braginskij, W.W. Witrianskij, op. cit., s. 294.

33 Potwierdzało to orzecznictwo: „Darowizna rzeczy ruchomej nie wymaga formy pisemnej (S.C. 928/71)”; „Darowizna rzeczy ruchomej dokonywa się albo przez wydanie jej obdarowanemu, albo, jeżeli w momencie darowizny faktyczne wydanie rzeczy darowanej z jakiegobądź powodu nie nastąpiło, przez sporządzenie zobowiązania pisemnego, przyczem w tym przypadku każdy dokument, mogący być z mocy ustawy dowodem istnienia stosunku prawnego, może być przyjęty na stwierdzenie dokonanej darowizny rzeczy ruchomej (S.C. 473/75, 86/13)", cyt. za: Prawo cywilne Ziem..., s. 585.

34 G.F. Szerszeniewicz, op. cit., s. 339; M.I. Braginskij, W.W. Witrianskij, op. cit., s. 294. 
odmówić dokonania darowizny. Prawo własności nabywało się później poprzez wejście w posiadanie ${ }^{35}$.

Według postanowień art. $991 \mathrm{t}$ X, cz. 1 za akty darowizny należało uznawać testamenty, mocą których majątek został bezpowrotnie utwierdzony na inną osobę jeszcze za życia właściciela. Natomiast akty darowizny, na mocy których majątek miał przejść w obce posiadanie dopiero po śmierci darującego, stanowiły akty testamentowe. $\mathrm{Z}$ kolei intromisji do majątków nieruchomych z mocy aktu darowizny należało dokonywać niezwłocznie po sporządzeniu aktu i nie wolno było jej odkładać do śmierci darującego. Brzmienie art. 991 t. X, cz. 1 powodowało pewne wątpliwości. Problem dotyczył prawidłowego rozróżnienia aktu darowizny od testamentu, co widoczne było w orzeczeniach sądowych ${ }^{36}$.

\section{KONSEKWENCJE NARUSZENIA UMOWY DAROWIZNY}

Z umowy darowizny zazwyczaj wynikał jednostronny obowiązek, w którym darczyńca występował jako dłużnik, a obdarowany jako wierzyciel. Jednak dla darczyńcy, będącego dłużnikiem, przewidziano specjalne regulacje prawne wynikające $\mathrm{z}$ nieuzasadnionego charakteru darowizny, ponieważ darczyńca powiększał własność obdarowanego kosztem własnego majątku, nie nabywając niczego w zamian. W związku z tym w przypadku niewypełnienia lub nienależytego wypełnienia obowiązku wynikającego z umowy darowizny niemożliwe było zastosowanie wobec darczyńcy, bez żadnych wyjątków, ogólnych konsekwencji przewidzianych w stosunku do wadliwego dłużnika w ramach zobowiązania cywilnego ${ }^{37}$.

Pogląd ten widoczny był w doktrynie rosyjskiej, gdzie uwzględniona została szczególna pozycja prawna darczyńcy wynikająca ze stosunków prawnych związanych z umową darowizny. Według Szerszeniewicza odpowiedzialność darczyńcy nie może być nadmierna z uwagi na nieodpłatny, nieuzasadniony charakter darowizny, a więc jeśli podarunek składał się z obowiązku przekazania rzeczy, to

35 G.F. Szerszeniewicz, op. cit., s. 339-340; M.I. Braginskij, W.W. Witrianskij, op. cit., s. 294-295.

36 Wybrane orzeczenia: „Darowiznę uważa się z mocy przepisu art. 991 za rozporządzenie testamentowe tylko $\mathrm{w}$ tym razie, gdy przedmiot darowizny zgodnie $\mathrm{z}$ wolą darującego ma dopiero po jego śmierci przejść na własność obdarowanego, i przeto darowizna rzeczy ruchomej, dokonana zapomocą wręczenia jej przez darującego obdarowanemu, chociażby na krótko przed jego śmiercią, nie może być poczytana za ustne rozporządzenie testamentowe, o którem mówi art. 1023 (S.C. 550/68)”; „Akt darowizny tym różni się zasadniczo od testamentu, iż od chwili wydania go utwierdza prawo własności obdarowanego do będącego przedmiotem darowizny majątku, podczas gdy na mocy testamentu prawo własności do zapisanego w nim majątku przechodzi dopiero od dnia śmierci testatora (S.C. 578/76)", cyt. za: Prawo cywilne Ziem ..., s. 584-585.

37 M.I. Braginskij, W.W. Witrianskij, op. cit., s. 298. 
darczyńca przed przekazaniem mógł ponosić odpowiedzialność tylko w przypadku złego zamiaru lub rażącego zaniedbania ${ }^{38}$.

Dla ważności darowizny ważne było, aby była ona dokonana z wolnej i nieprzymuszonej woli ${ }^{39}$. Poza tym, zgodnie z art. 973 t. X, cz. 1, do ważności darowizny potrzebne było jej przyjęcie ze strony obdarowanego.

\section{ZWROT DAROWIZNY}

Możliwość zwrotu darowizny (anulowania/odwołania darowizny) została uznana przez rosyjskich prawników za szczególną cechę, która była nieodłącznie związana z umową darowizny ${ }^{40}$.

Zgodnie z postanowieniami t. X, cz. 1 zwrot darowizny mógł nastąpić: a) z powodu niewdzięczności obdarowanego (art. 974 t. X, cz. 1), b) przy niespełnieniu warunku lub zlecenia (modus) nałożonego przy darowiźnie na obdarowanego (art. 975, 976 t. X, cz. 1), c) z powodu bezpotomnej śmierci obdarowanych dzieci rodzonych i adoptowanych (art. 1142 t. X, cz. 1), d) z powodu niewypłacalności obdarowującego ${ }^{41}$. Zwrot darowizny mógł nastąpić tylko w takich przypadkach ${ }^{42}$.

a) Przepisy art. 974 t. X, cz. 1 stanowiły, że darowizna z reguły nie powracała do darującego, dopuszczały jednak jej zwrot w przypadku niewdzięczności obdarowanego. Za taką uznawano zamach na życie darującego, jego pobicie lub grożenie mu, oszczercze zarzucenie mu przestępstwa lub jawne okazanie szacunku wobec darującego ${ }^{43}$. Obdarowany, do czasu rozstrzygnięcia prawomocnym wyrokiem sądu sporu z darującym o zwrot darowizny, uważany był w obliczu prawa i wszystkich osób za prawowitego właściciela darowanego majątku ${ }^{44}$.

38 G.F. Szerszeniewicz, op. cit., s. 342; M.I. Braginskij, W.W. Witrianskij, op. cit., s. 298-299.

39 „Nikt nie może być zmuszony do wykonania uczynionej obietnicy podarowania, albowiem ustawa wymaga, aby darowizna była przejawem wolnej i nieprzymuszonej woli darującego" (S.C. 12/82), cyt. za: Prawo cywilne Ziem..., s. 573.

40 M.I. Braginskij, W.W. Witrianskij, op. cit., s. 301.

${ }^{41}$ F. Bossowski, op. cit., s. 201.

42 ,Zwrot daru może być żądany tylko w przypadkach wyraźnie wymienionych w ustawie (S.C. 17/68)", cyt. za: Prawo cywilne Ziem..., s. 576.

43 G.F. Szerszeniewicz, op. cit., s. 340-341; sądy za przypadki jawnego nieposzanowania uznawały: „Przy rozstrzyganiu pytania, czy w czynach obdarowanego zawierają się oznaki jawnego nieposzanowania w stosunku do darującego, sąd obowiązany jest brać pod uwagę też i zachowanie samego darującego, które spowodowało powyższe czyny obdarowanego, i na podstawie całego tego materiału dowodowego określić, czy zachodzi w danym przypadku to nieposzanowanie ze strony obdarowanego, o którem mówi art. 974 (S C. 54/10); „Zgłoszenie przez obdarowanego żądania wydania mu przedmiotu darowizny nie może być uważane za okazanie przez niego darującemu jawnego nieposzanowania (S.C. 12/82)", cyt. za: Prawo cywilne Ziem..., s. 576.

44 „Do czasu rozstrzygnięcia prawomocnym wyrokiem sądowym sporu o zwrot daru lub też zabezpieczenia powództwa w tym przedmiocie na majątku, będącym przedmiotem darowizny, obdarowany winien być w obliczu prawa i wszystkich osób trzecich uważany za prawowitego właści- 
b) Postanowienia art. 975 i 976 t. X, cz. 1 dotyczyły zwrotu darowizny przy niespełnieniu warunku lub zlecenia (modus) nałożonego przy darowiźnie na obdarowanego.

Zgodnie z art. 975 t. X, cz. 1 darowiznę pomiędzy osobami prywatnymi można było czynić na warunkach, co do sposobu użytkowania i zarządzania darowanym majątkiem, jakie darujący uznawał za dobre, byleby tylko było to zgodne z przepisami prawa. Natomiast według art. 976 t. X, cz. 1 jeżeli darowiznę uczyniono pod warunkiem, a obdarowany nie spełnił go, to darowiznę należało zwrócić darującemu.

Interpretacja artykułów dotyczących zwrotu darowizny, zwłaszcza art. 975 t. X, cz. 1, przysporzyła wiele problemów zarówno w doktrynie, jak i praktyce. Odniósł się do tego Leon Sumorok, który w swoim artykule dotyczącym darowizny w t. X, cz. 1 podaje za K. Annienkowem stanowiska poszczególnych przedstawicieli doktryny, którzy odnosili się do postanowień t. X, cz. $1 \mathrm{w}$ zakresie zwrotu darowizny ${ }^{45}$.

Treść przepisów art. 975-977 t. X, cz. 1 była również interpretowana przez polskie orzecznictwo ${ }^{46}$.

c) T. X, cz.1 dopuszczał jeszcze jeden wyjątek związany ze zwrotem darowizny. Zgodnie z postanowieniami art. $1142 \mathrm{t}$. X, cz. $1 \mathrm{w}$ razie bezpotomnej śmierci obdarowanych dzieci rodzonych i adoptowanych następował zwrot darowizny, która wracała do rodziców nie tytułem spadku, ale jako darowizna ${ }^{47}$. W tym przypadku przepisy t. X, cz. 1 interpretowały wolę obdarowującego w sposób ścieśniający i podsuwały tej woli dodanie warunku rozwiązującego ${ }^{48}$.

d) Poza wymienionymi przypadkami zwrot darowizny mógł nastąpić z powodu niewypłacalności obdarowującego.

Sytuacja taka miała miejsce, gdy obdarowanego uznano za niewypłacalnego w związku z otwarciem konkursu do jego majątku. Związane to było z częstą praktyką, polegającą na próbie ratowania swego majątku przez niewypłacalnego

ciela podarowanego mu majątku i w tym charakterze władny jest, z mocy art. 541 t. X cz. I Zw. Pr, zastawić rzeczony majątek, przyczem zastaw taki, jako dokonany na majątek wolny od zakazu, nie może być obalony, nawet gdyby następnie powództwo, wytoczone przez darującego, zostało uwzględnione (S.C. 62/86)", cyt. za: Prawo cywilne Ziem..., s. 576.

45 Szerzej zob. L. Sumorok, op. cit., s. 181-186.

46 Wybrane orzeczenia: „Użyte w art. 975 wyrażenie »warunki« dotyczące sposobu użytkowania i zarządu majątku »podarowanego« nie jest ścisłe, mieszcząc w sobie obszerniejszą treść niż na to wskazuje dosłownie jego brzmienie, i w myśl tego artykułu należy uznać za dopuszczalne zamieszczenie w akcie darowizny nawet warunków ograniczających obdarowanego pod względem rozrządzania otrzymanym w darze majątkiem (S.N. 114/27)”; „Przyczyna niewykonania przez obdarowanego przewidzianego $\mathrm{w}$ akcie darowizny warunku jest bez znaczenia i darowizna podlega powrotowi nawet wówczas, gdy obdarowany udowodni, że wykonanie powyższego warunku stało się dla niego niemożliwe z przyczyn prawnych (S.C. 7/04)", cyt. za: Prawo cywilne Ziem..., s. 577-578.

47 G.F. Szerszeniewicz, op. cit., s. 341; L. Sumorok, op. cit., s. 184.

48 F. Bossowski, op. cit., s. 201. 
dhużnika poprzez dokonanie pozornej darowizny na rzecz bliskiej rodziny. Jednak w celu ochrony wierzyciela niewypłacalnego dłużnika ustawa dopuszczała zaczepienie poczynionej darowizny. Aby można było z takiego zaczepienia skorzystać, dokonana alienacja pod tytułem darmym musiała być uczyniona: a) w przeciągu ostatnich dziesięciu lat przed ogłoszeniem niewypłacalności (otwarcia konkursu), b) na korzyść drugiego małżonka, a w sprawach handlowych także na rzecz dzieci lub innych krewnych, ale w takim przypadku mogła być obalona tylko, gdy zostało wykazane, że w chwili alienacji długi już przewyższały połowę jego majątku.

Obalenie darowizny z powodu niewypłacalności obdarowującego powodowało, że obdarowujący (jego masa konkursowa) z powrotem stawał się właścicielem rzeczy lub prawa, których się już pozbył, nawet wówczas, gdy przeszły już w ręce osób trzecich.

W pozostałych przypadkach zwrotu darowizny, to jeśli rzecz darowana przeszła już na własność osób trzecich, obdarowany obowiązany był jedynie do zwrotu wartości rzeczy ${ }^{49}$.

\section{RODZAJE DAROWIZN}

\subsection{OFIARA}

Ofiara (pożertwowanije) nazywana darowizną osoby prywatnej na rzecz państwa lub na rzecz innej osoby prawnej, której cele były ogólnospołeczne, traktowana była jako szczególna odmiana darowizny ${ }^{50}$. Zgodnie z art. 979 t. X, cz. 1 była ona dobrowolną darowizną majątku na pożytek powszechny, gdzie obdarowanym był podmiot prawny o znaczeniu publicznym. Oznakami szczególnymi dla tego rodzaju darowizny były: a) osoba prywatna jako dawca oraz b) ogólna korzyść jako cel darowizny.

W związku z tym za ofiarę uznawane było darowanie na rzecz państwa, miasta, instytucji edukacyjnej, towarzystwa akademickiego itp., przynoszące korzyść nieokreślonej liczbie osób, które mogły korzystać z przekazanych rzeczy ${ }^{51}$.

Ofiara mogła być uczyniona za życia ofiarodawcy lub w drodze zapisu testamentowego ${ }^{52}$. Ofiara stanowiła zobowiązanie ofiarodawcy, stąd nie mogła być ona przez niego cofnięta jednostronnie. Wymagana był do tego zgoda obdarowanego lub inne przyczyny prawne ${ }^{53}$.

49 G.F. Szerszeniewicz, op. cit., s. 341-342; F. Bossowski, op. cit., s. 201-202.

50 F. Bossowski, op. cit., s. 200-201.

51 G.F. Szerszeniewicz, op. cit., s. 342; M.I. Braginskij, W.W. Witrianskij, op. cit., s. 308-309.

52 Orzeczenie Sądu Cywilnego: „Ofiara może być uczyniona pod postacią darowizny za życia oraz w drodze zapisu testamentowego (S.C. 25/98)", cyt. za: Prawo cywilne Ziem ..., s. 577-578.

53 Orzeczenie Sądu Cywilnego: „Ofiara, stanowiąc zobowiązanie, może być cofnięta tylko za zgodą obdarowanego lub $\mathrm{z}$ innych prawnych przyczyn, a nie jednostronnie przez ofiarodawcę 
Zgodnie z art. 980 t. X, cz. 1 ofiary mogły być czynione według uznania ofiarodawcy i nie podlegały żadnym przepisom szczególnym. Mogły być czynione zarówno z majątków ruchomych i kapitałów, jak i majątków nieruchomych, na rzecz zakładów i towarzystw dobroczynnych, szkół i innych instytucji oraz na rzecz inwalidów ${ }^{54}$.

Ofiary na cele dobroczynne złożone na rzecz instytucji ziemskich podlegały ogólnym postanowieniom o nabywaniu majątków przez ziemstwo (art. 982 t. X, cz. 1).

Natomiast odrębne postanowienia dotyczyły ofiary na rzecz instytucji kościelnych. Zgodnie z art. 984 t. X, cz. 1 ofiarę na kościół mogli składać dobrowolni ofiarodawcy. Mogła być ona złożona w pieniądzach lub majątku ruchomym, zwłaszcza w obrazach świętych, w ozdobach i innych przedmiotach przeznaczonych do użytku kościelnego. Poza tym ofiara majątku nieruchomego na rzecz cerkwi i klasztorów podlegała szczególnym ograniczeniom wynikającym z postanowień art. 985 t. X, cz. 1.

Z kolei art. 986 t. X, cz. 1 stanowił, że majątek ofiarowany powinien być używany zgodnie z przeznaczeniem ofiarodawcy. W przypadku nieprzestrzegania tego postanowienia ofiarodawca lub jego spadkobiercy mogli domagać się zwrotu ofiary. Jeżeli ten cel nie mógł być osiagnięty z powodu zmiany okoliczności, na przykład w wyniku zamknięcia instytucji edukacyjnej, na rzecz której darowizna została przekazana, to ofiarowany majątek można było przeznaczyć na inny cel dopiero po uzyskaniu zgody ofiarodawcy. Jeśli ofiarodawca już nie żył i za życia nie zostawił szczególnych wskazówek w tym przedmiocie, albo gdy wykonanie ofiary zgodnie z jego wskazówkami uznane było za niemożliwe, wtedy należało uzyskać zezwolenie u władzy najwyższej55.

\subsection{NADANIE}

Poza ofiarą t. X, cz. 1 przewidywał także inną odmianę ogólnego pojęcia darowizny. Było to nadanie (pożałowanije), nazywane darowizną nieruchomości dokonaną przez naczelnika państwa z majątku państwa na rzecz osoby prywatnej ${ }^{56}$.

pod pretekstem, że brakuje mu środków lub że obdarowana instytucja nie potrzebuje już wsparcia pieniężnego (S.O. 21/09; S.C. 91/10)", cyt. za: Prawo cywilne Ziem ..., s. 577-578.

54 Warto w tym miejscu wspomnieć o dekrecie Naczelnika Państwa z dnia 7 lutego 1919 roku o fundacjach i o zatwierdzeniu darowizn i zapisów (Dz.U. z 1919 r. Nr 15, poz. 215) ze zmianami wprowadzonymi rozporządzeniem Prezydenta RP z dnia 22 marca 1928 roku (Dz.U. z 1928 r. Nr. 38, poz. 372), którego postanowienia należało brać pod uwagę przy analizie przepisów dotyczących ofiary w t. 10, cz. 1.

55 G.F. Szerszeniewicz, op. cit., s. 343; F. Bossowski, op. cit., s. 202.

56 F. Bossowski, op. cit., s. 200-201. 
Przepisy o nadaniu zostały w t. X., cz. 1 wyodrębnione od przepisów właściwych dla darowizny i znalazły się w osobnym rozdziale ${ }^{57}$.

W doktrynie nadanie traktowano jako szczególną odmianę darowizny, a według Meiera nadanie należało traktować nie jako instytucję dotyczącą zobowiązań cywilnych, ale jako instytucję prawa publicznego ${ }^{58}$.

\subsection{DAROWIZNA MIĘDZY MAŁŻONKAMI}

$\mathrm{W}$ prawie rosyjskim - $\mathrm{w}$ przeciwieństwie do innych ustawodawstw europejskich, w tym do rozwiązań przyjętych w KN, ABGB i BGB - nie znalazły się żadne szczególne uregulowania dotyczące darowizny między małżonkami ${ }^{59}$. Jedynie w art. 978 t. X, cz.1 zawarto definicję dopuszczającą możliwość dokonywania przez małżonków darowizny między sobą na takich samych zasadach, jak pomiędzy osobami obcymi, a więc darowizny między małżonkami nie były w t. X, cz.1 zabronione ${ }^{60}$.

\subsection{WYDZIELENIE I CEL POSAGU}

W t. X, cz.1 uznano również podział i cel posagu za odrębne rodzaje darowizn $^{61}$. W art. 994-1000 znalazły się przepisy o wydzieleniu majątku przez rodziców i wstępnych na rzecz dzieci i potomków, a w art. 1001-1008 — przepisy o posagu.

Zgodnie z art. 994 wydzielenie rozumiano jako dar przekazany przez rodziców i wstępnych swoim dzieciom i potomkom ${ }^{62}$. Za potomków uznawano tylko zstępnych, a nie bocznych krewnych. Oddanie przez daną osobę swojego majątku

$57 \mathrm{~W}$ rozdziale I ( $O$ nadaniu: art. 934-960) działu pierwszego ( $O$ nabywaniu praw majątkowych pod tytutem darmym czyli bezplatnym) księgi trzeciej (O trybie nabywania i utwierdzenia praw majątkowych w szczególności).

58 Według D.I. Meiera nadanie nie powinno być traktowane jako rodzaj umowy darowizny i w ogóle nie dotyczyło stosunków cywilnoprawnych. Badacz podkreślał, że darowizny od państwa nie można uznać za specjalny rodzaj darowizny, chociaż noszą specjalną nazwę (nadanie). Sam akt państwa nie nadaje jej jeszcze znaczenia niezależnej instytucji prawnej, a cechy określone w przepisach dotyczących nadania nie dotyczą istoty darowizny, ale mają jedynie znaczenie administracyjne. W ten sposób uznawał nadanie nie jako instytucję dotyczącą zobowiązań cywilnych, ale jako instytucje prawa publicznego. Podobne stanowisko zajęli M.I. Braginskij, W.W. Witrianskij, zob. D.I. Meier, op. cit., s. 237; M.I. Braginskij, W.W. Witrianskij, op. cit., s. 308. W związku z tym, że nadanie było darowizną szczególnego rodzaju, odbiegającą znacząco od pojęcia darowizny zwykłej, w pracy tej nie poświęcono jej więcej miejsca, zob. jednak Prawo cywilne Ziem..., s. 563-572; G.F. Szerszeniewicz, op. cit., s. 343; M.I. Braginskij, W.W. Witrianskij, op. cit., s. 307-308.

59 F. Bossowski, op. cit., s. 201.

60 D.I. Meier, op. cit., s. 239-240.

61 Ibidem, s. 238; M. I. Braginskij, W.W. Witrianskij, op. cit., s. 309.

62 D.I. Meier, op. cit., s. 238; M.I. Braginskij, W.W. Witrianskij, op. cit., s. 309. 
krewnemu w linii bocznej nie było wydzieleniem, ale darowizną ${ }^{63}$. Wydział spadkowy miał odmienny cel od zwykłej darowizny, jednak posiadał wspólne znamiona szczodrobliwości i podlegał skutkom niewdzięczności ze strony obdarowanego na zasadach art. 974 t. X., cz. $1^{64}$. Obdarowanie w trybie art. 994 odbywało się przy zachowaniu formy aktu notarialnego (art. 1000 t. X, cz. 1) ${ }^{65}$.

Zgodnie z art. 1001 wydzielenie córek i krewnych z powodu ich zamęścia dokonywało się przez wyznaczenie im posagu. Natura prawna wydzielenia i posagu była identyczna ${ }^{66}$. Posag w znaczeniu wydziału spadkowego mógł być wyznaczony tylko na rzecz zstępnych, a nie na rzecz krewnych w linii bocznej ${ }^{67}$. Jako szczególny rodzaj darowizny posag podpadał pod przepis art. $1142 \mathrm{t}$. X, cz. 1 i po bezdzietnej śmierci dzieci powracał do rodziców ${ }^{6}$.

Przepisy t. X, cz. 1 nie rozstrzygały jednoznacznie, kiedy majątek podarowany córce przy wyjściu za mąż należy uznać za posag, a kiedy za zwykłą darowiznę, o formie tego aktu szczodrobliwości decydowali więc rodzice ${ }^{69}$.

\section{PODSUMOWANIE}

Regulacje dotyczące darowizny obowiązujące na ziemiach wschodnich byłego zaboru rosyjskiego miały swoją szczególną charakterystykę w porównaniu z przepisami o darowiźnie obowiązującymi na ziemiach pozostałych zaborów.

63 „Potomkami”, o których mówi art. 994, są tylko zstępni, a nie boczni krewni; oddanie przez daną osobę swego majątku za życia krewnemu stanowi nie wydzielenie, lecz darowiznę (S.C. 46/12)", cyt. za: Prawo cywilne Ziem..., s. 585.

64 ,Wydział spadkowy na rzecz domniemanego spadkobiercy, jakkolwiek w celach swych odmienny od zwykłej darowizny, posiada wszakże wspólne znamiona szczodrobliwości, w równej więc mierze ulega działaniu przepisu art. 974 t. X, cz. I Zwodu praw, który dotyczy skutków niewdzięczności ze strony obdarowanego. (S. N. 187/26)", cyt. za: Prawo cywilne Ziem..., s. 585.

65 Szerzej o wydzieleniu zob. Prawo cywilne Ziem..., s. 585-588.

66 „Natura prawna posagu i wydzielenia jest identyczna (S.C. 16/10)”, cyt. za: Prawo cywilne Ziem..., s. 588.

67 „Posag w znaczeniu wydziału spadkowego może być wyznaczony tylko na rzecz zstępnych, a nie na rzecz krewnych w linji bocznej; wymienienie w art. 1001 prócz córek też $\mathrm{i} » k r e w n y c h «$ należy rozumieć w ten sposób, że mowa tu o krewnych w linji prostej zstępnej, to jest o wnuczkach i prawnuczkach, nie zaś o siostrach, siostrzenicach czy bratanicach i innych bocznych krewnych (S.C. 72/13)", cyt. za: Prawo cywilne Ziem..., s. 588.

68 „Posag, stanowiąc darowiznę, podpada pod przepis art. 1142 t. X., cz. I Zwodu praw, z mocy którego majątek, podarowany przez rodziców dzieciom, powraca po bezdzietnej śmierci tych ostatnich do rodziców. (S.C. 279/67)", cyt. za: Prawo cywilne Ziem..., s. 588.

69 „Ustawa nie zawiera takiego przepisu, iżby majątek, podarowany córce przy wyjściu jej za mąż, zawsze winien być uważany za posag, i od rodziców zależy, czy nadać temu aktowi szczodrobliwości formę posagu czy też zwykłej darowizny; oddanie mienia przez rodziców córce w charakterze posagu może być udowodnione tylko za pomocą aktu posagowego, natomiast zwykła darowizna, o ile dotyczy rzeczy ruchomej, może być stwierdzona i przez świadków (S.C. 889/74)", cyt. za: Prawo cywilne Ziem..., s. 590. 
Wiązało się to nie tylko z brzmieniem poszczególnych artykułów, ale także ze specyficzną regulacją dotyczącą szczególnych rodzajów darowizny (nadanie i ofiara, wydzielenie i posag) oraz z umiejscowieniem darowizny w systematyce rosyjskiego prawa cywilnego, czyli w części ogólnej, a nie w zobowiązaniach.

W polskiej doktrynie z okresu II RP regulacje darowizny zawarte w t. X, cz. 1 nie cieszyły się zbytnim uznaniem, co było widoczne w trakcie prac nad polskim kodeksem zobowiązań z 1933 roku, na który przepisy rosyjskie w zakresie umowy darowizny miały znikomy wpływ, w przeciwieństwie do niemieckiego kodeksu cywilnego $(\mathrm{BGB})^{70}$. Ponadto, jak wynika z przedstawionego orzecznictwa sądów polskich, przepisy o darowiźnie z t. X, cz. 1 budziły nierzadko niejasności i wątpliwości interpretacyjne.

\title{
CHARACTERISTICS OF THE PROVISIONS ON GIFTS IN FORCE IN THE EASTERN TERRITORIES OF THE FORMER RUSSIAN PARTITION UNDER THE DIGEST OF LAWS OF THE RUSSIAN EMPIRE
}

\begin{abstract}
Summary
During the period of partitions of Poland, as well as in the interwar period, in the eastern territories of the Russian partition, the so-called Eastern Borderlands, the provisions on gift contained in Volume X, Part 1 of The Digest of Laws of the Russian Empire of 1832 were in force - Swod zakonov Rossijskoj impierii.

The individual provisions on gift contained in The Digest of Laws of the Russian Empire, taking into account the position of polish and russian doctrine and the jurisprudence of polish courts have been analyzed in the article.

In comparison with the other partition regulations, i.e. the Civil Code of Germany (BGB), the Civil Code of Austria (ABGB) and the Napoleonic Code, the provisions concerning gift contained in the The Digest of Laws of the Russian Empire were characterised by specific regulations concerning mainly particular types of gift, such as bestowal and offering, separation and dowry, as well as by placing gift in the systematics of civil law, i.e. in the general part, and not, as it was the case in the other district legislations, i.e. in the part devoted to obligations.
\end{abstract}

Keywords: gift, The Digest of Laws of the Russian Empire, civil law during the partitions of Poland, civil law in the Second Polish Republic, code of obligations

70 Zob. L. Domański, op. cit., s. 136-178; R. Longchamps de Berier, op. cit., s. 79-117. 


\section{BIBLIOGRAFIA}

Prawo cywilne Ziem Wschodnich. Tom X, cz. I Zwodu praw rosyjskich, przeł i oprac. Z. Rymowicz, W. Święcicki, t. 1, Warszawa 1932; t. 2, Warszawa 1933.

Bossowski F., Zoll F., Prawo cywilne dzielnic polskich w zarysie, cz. 4. Prawo cywilne Ziem Wschodnich, na podstawie dzieła Szerszeniewicza oprac. F. Bossowski, Warszawa-Kraków 1922.

Braginskij M.I., Witrianskij W.W., Dogowornoje Prawo, Moskwa 2011.

Domański L., Instytucje kodeksu zobowiązań. Komentarz teoretyczno-praktyczny. Część szczególna, Warszawa 1938.

Longchamps de Berier R., Uzasadnienie projektu Kodeksu Zobowiązań z uwzględnieniem ostatecznego tekstu Kodeksu: art. 294-369, „Komisja Kodyfikacyjna. Podkomisja Prawa o Zobowiązaniach" 1937, z. 7.

Meier D.I., Russkoje grażdanskoje prawo, Sankt Peterburg 1864.

Pobiedonoscew K.P., Kurs grażdanskogo prawa, t. 3, Sankt Petersburg 1896.

Sójka-Zielińska K., Historia Państwa i Prawa Polski, t. 3. Od rozbiorów do uwłaszczenia, red. J. Bardach, M. Senkowska-Gluck, Warszawa 1981.

Sójka-Zielińska K., Historia prawa, Warszawa 2011.

Sumorok L., Darowizna wedlug cz. I, t. X. Zwodu praw, „Wileński Przegląd Prawniczy” 1933, nr 7. Szerszeniewicz G.F., Uczebnik russkogo grażdanskogo prawa, Moskwa 1995.

Till E., Longchamps de Berier R., Polskie prawo zobowiąań (część szczegółowa). Projekt wstęnyy z motywami, Lwów 1928. 